\title{
QUEEN'S
UNIVERSITY
BELFAST
}

\section{Institutional maintenance work and power preservation in business exchanges: Insights from industrial supplier workshops}

Palmer, M., Simmons, G., Robinson, P. K., \& Fearne, A. (2015). Institutional maintenance work and power preservation in business exchanges: Insights from industrial supplier workshops. Industrial Marketing Management, 48, 214-225. https://doi.org/10.1016/j.indmarman.2015.03.017

Published in:

Industrial Marketing Management

Document Version:

Peer reviewed version

Queen's University Belfast - Research Portal:

Link to publication record in Queen's University Belfast Research Portal

Publisher rights

(c) 2015 Elsevier Inc. This manuscript version is made available under the CC-BY-NC-ND 4.0 license http://creativecommons.org/licenses/bync-nd/4.0/,which permits distribution and reproduction for non-commercial purposes, provided the author and source are cited.

\section{General rights}

Copyright for the publications made accessible via the Queen's University Belfast Research Portal is retained by the author(s) and / or other copyright owners and it is a condition of accessing these publications that users recognise and abide by the legal requirements associated with these rights.

Take down policy

The Research Portal is Queen's institutional repository that provides access to Queen's research output. Every effort has been made to ensure that content in the Research Portal does not infringe any person's rights, or applicable UK laws. If you discover content in the Research Portal that you believe breaches copyright or violates any law, please contact openaccess@qub.ac.uk. 


\title{
Institutional maintenance work and power preservation in business exchanges: Insights from industrial supplier workshops
}

\author{
Professor Mark Palmer* \\ Queen's University Management School \\ Queen's University Belfast \\ Riddel Hall \\ 185 Stranmillis Road \\ Belfast BT9 5EE \\ Northern Ireland \\ m.palmer@qub.ac.uk

\section{Dr Geoff Simmons} \\ Queen's University Management School \\ Queen's University Belfast \\ Riddel Hall \\ 185 Stranmillis Road \\ Belfast BT9 5EE \\ Northern Ireland \\ g.simmons@qub.ac.uk
}

\section{Dr Pamela K. Robinson}

Birmingham Business School

University of Birmingham

University House

Edgebaston,

Birmingham B15 2TY

UK

p.k.robinson@bham.ac.uk

Professor Andrew Fearne

Kent Business School

University of Kent

Canterbury,

Kent, CT2 7PE

UK

A.Fearne@kent.ac.uk

\section{* Corresponding author}


Mark Palmer is a Professor of Marketing at Queen's University Belfast. Before joining Queen's University Management School, he worked at the University of Birmingham, Aston University and also held visiting positions at EDHEC, France, and also SIM in Singapore. His research interests are market-driving behaviors, institutions and innovation. His work has been published in Industrial Marketing Management, European Journal of Marketing, Journal of Marketing Management, Journal of Strategic Marketing, International Marketing Review, Studies in Higher Education, International Business Review, Organization, Journal of Economic Geography and Environment and Planning A.

Geoff Simmons is a Senior Lecturer of Marketing at Queen's University Belfast. His research interests are in the influence of technology on marketing strategy and marketing strategy's influence on business-level strategy. His work has been published in among others European Journal of Marketing, Industrial Marketing Management, Journal of Marketing Management, International Small Business Journal, Environment \& Planning A, Journal of Strategic Marketing, Studies in Higher Education, International Journal of Entrepreneurship and Innovation.

Pamela K. Robinson is a Lecturer in Comparative Employment Relations at the University of Birmingham. Before joining the Business School she was a Post-Doctoral Fellow in the School of Social Sciences and a Research Associate at the Centre for Business Relationships Accountability, Sustainability and Society (BRASS) at Cardiff University. Previously she was employed in the retail sector in a number of senior management roles, with responsibility for buying and marketing of food products. Her work has been published in Competition and Change, Journal of Industrial Relations, Journal of Business Ethics and Journal of International Development.

Andrew Fearne is a Professor of Value Chain Management and the Director of the Centre for Value Chain Research at Kent Business School, University of Kent. Andrew studied for his PhD in agricultural economics at Newcastle University, where he spent six years as a lecturer in food marketing. In 1994 he moved to Wye College, University of London, where he established the Centre for Food Chain Research. In February 2005 he took up a position as principal research fellow at Kent Business School, University of Kent. His work has been published, amongst others, in International Journal of Information Management, Journal of Risk Research, Supply Chain Management: An International Journal, International Journal of Market Research, International Journal of Retail and Distribution Management, Journal of Business and Industrial Marketing, Development Policy Review, Supply Chain Management and Journal of Farm Management. 


\section{Research Highlights:}

- Demonstrates how power is a property of institutional maintenance work.

- Recognizes the significance of temporary industrial workshop settings for maintaining power.

- Provides insights into how the work of institutional maintenance 'bears down' on buyer and seller exchanges.

- Elucidates priming work activity and pressure specialist mechanisms for legitimation or relegitimation of roles and expectations.

- Shows power intensification in the instituting and normalizing of distinct in-group market rules. 


\title{
Institutional maintenance work and power preservation in business exchanges: Insights from industrial supplier workshops
}

\begin{abstract}
This paper aims to offer new theoretical and empirical insights into power dynamics in an industrial supplier workshop setting. Theoretically, it advances an institutional perspective on supplier workshops as an important venue in managing, preserving and instituting industrial market power. Based on a detailed ethnographic analysis of an industrial workshop setting, this article investigates the institutional maintenance work of Retail Co. in preserving the power dynamics of market dominance in business exchanges and market structures. Our findings revealed three previously unreported insights into the subtle, but nonetheless pervasive power from institutional maintenance work in an industrial workshop setting. First, the institutional workshop work comprised a cultural performance; constituting socialization practice through a performance game, the power of numbers in field comprehension and an award ceremony. Second, the institutional workshop work mobilized projective agency, stipulating, directing and appealing for the instituting of distinct market rules and collective identities. Finally, the institutional workshop work increases supplier docility and utility via the regulative technologies-of-the-self to enhance business planning, operations and market decision-making practice, without necessarily being seen to be disciplinarian.
\end{abstract}

Keywords: institutions, power, industrial marketing, workshops, marketing strategy. 


\section{Institutional maintenance work and power preservation in business exchanges: Insights from industrial supplier workshops}

\section{Introduction}

Studies suggest that maintaining market leadership is dependent on power (Clegg, 1987, 1989). While there exists a range of insights on power in business-to-business exchanges including, how power is exercised in purchasing (Cho \& Chu, 1994); the locus of power (Meehan \& Wright, 2007), its drivers (Caniëls \& Gelderman, 2007; Sheu \& Hu, 2009), we know much less about how such power is maintained in the social structures of an industrial market. In recent reviews on industrial market power dynamics, Meehan \& Wright (2012) and Blois \& Hopkinson (2013) emphasized that there is a need to re-examine the units of analysis research bias at an organizational or individual level of business exchanges. As a consequence, research has typically remained on the macro-level of firms, regulators and markets while several complex ways in which the social workings of power 'bear down' (Hardy, 2004; Kumar, 2005) on industrial market settings has been neglected. Hingley (2005a) suggests that it is necessary to refocus research on power, paying more attention to new relational theoretical approaches and methodological units of analysis including micro-institutional arrangements, logics and venues.

In the present study we concentrate on the unit of analysis of the industrial workshop; a line of enquiry that conceptualizes the industrial workshop as an institutional arrangement and venue for developing and maintaining business-to-business exchanges; transmitting and ensuring that institutional logics of the dominant buyer persist in the face of supplier disruption, challenges and challengers. We argue that the level of analysis of the industrial workshop is particularly relevant to industrial marketing practice, yet has largely been ignored in the literature. In particular, we explore the complex way in which the workings of power are practiced within, and generated from, institutional arrangements such as an industrial workshop. In this way, we adopt an institutional theoretical perspective (DiMaggio \& Powell, 1983; Lawrence, Suddaby \& Leca, 
2011), to develop greater insights into how the workings of power shape the institutional work of industrial market actors (see Yang \& Su, 2014, for a recent special issue on the role of institutions in industrial marketing). Here, institutional work is defined as 'purposive action of individuals and organizations aimed at creating, maintaining and disrupting institutions' (Lawrence \& Suddaby, 2006: 214).

The overall aim of this article is to explore the various ways in which the workings of power is intertwined with institutional work and arrangements, specifically in an industrial supplier workshop, in the functioning of industrial markets. We therefore acknowledge calls for an extension of thinking of power beyond firm-level unit of analysis (Hardy, 2004; Hingley (2005a Kumar, 2005), towards a conceptualization of how power circulates in the institutional functioning of the industrial workshop. Specific research questions are concerned with how does the practice of an industrial workshop setting shape buyer-seller relations, and how do these stabilizing and maintenance work 'bear down' on buyer and seller exchanges. We first address these questions by drawing primarily from an institutional analysis of power. We then provide a relevant case study illustration of a dominant firm - termed Retail Co - within an industrial supplier workshop held in a region of the UK. This is triangulated with evidence from observations made by one of the researchers at other workshops held by Retail Co in other regions across the UK supply chain (i.e. Belfast, Peterborough, Cardiff, Warrington and York). Addressing the research aim and questions, we attempt to move the ongoing power debate on from normative issues around whether power is exercised or not, towards a discussion on the various explanatory ways in which maintaining power is practiced.

In this respect three new insights are provided. First, the paper begins a new line of enquiry in the industrial marketing literature on the role of industrial workshop venue in buyer-seller behaviour (Hingley, 2005a, 2005b) and recognizes the significance of discrete, episodic relational institutional arrangements and mechanisms for maintaining power, structures and institutions (Kumar, 2005; Yang \& Wang, 2011). The industrial workshop as a unit of analysis 
opens up an understanding of institutional work that is commensurate with the interaction approach (Håkansson, 1982) and builds on the view of multiple embedded power structures posited by the traditions of the Industrial Marketing and Purchasing (IMP) Group (Ford, Gadde, Håkansson, Snehota, \& Waluszewski, 2003; Meehan \& Wright, 2012; Peters, Pressey, Vanharanta, \& Johnson, 2013). Second, this study makes an important contribution to Lawrence \& Suddaby’s (2006) study, and related research in business marketing (Kumar, 2005; Jia, Cai \&Xu, 2014; Yang \& Wang, 2011) on agentic power by showing how institutional work constituted subjects - the suppliers - transposing and mobilizing them with 'drama' in the sense of fictionalised representation of games, ceremonial awards and new distribution inititatives. Specifically we identify the role of this 'priming work' as both a sign and consequence of esousing competitive tensions and shaping aspirational organizational identity in supplier networks.

Third, Retail Co sought to reaffirm standard compliance rules within the wider social knowledge system of doing business with the firm, drawing on the agency of a senior member of the firm. The findings therefore provide insights into the institutional maintenance work at the industrial supplier workshop (Scott, 2001), particularly the way that both the 'pressure specialist' (Lipsky, 1980) and institutional complementarity transmits institutionalized roles and interactive patterns of suppliers. This analysis thus expands our understanding of the subtle 'cognitive anchoring work' associated with the projective agency of stipulating, directing and appealing within the context of three strategic agenda-setting issues - strategic planning, operations and market intelligence decision-making - and how these may be used how they may be used for legitimation or relegitimation of institutionalized roles and expectations. Finally, the study builds on extant studies regarding power intensification (Hardy \& Thomas, 2014), demonstrating how an institutional industrial workshop work increases supplier docility and utility with the discourses of projective compliance and an affiliated way of knowing and a system of knowledge, without necessarily being seen to be disciplinarian in the instituting and normalizing of distinct in-group market rules. This adds to Knights \& Willmott (1989) work on the role of power as subjectification through the intensification of voluntary technologies-of-the-self - that 
is, with self-examination and 'calculative' assessments via the maintenance of 'the rules of engagement' for enhancing business planning, operations and market decision-making practice.

The first part of the paper presents a literature review relevant to the research aim. Building on this, the second part of the paper outlines the qualitative research design chosen to address the research aim. Developed from the research findings we present a discussion section, explicating theoretical, normative and research contributions before conclusions are drawn.

\section{Literature perspectives}

In this section literature is reviewed relating to the research aim and questions. To begin with, the way that power is property of buyer-seller institutions is outlined. This provides a basis for synthesizing the workings of power within the institutional work undertaken within an industrial supplier workshop. Throughout, the IMP literature is reviewed, noting complementarities with recent thinking regarding institutional power.

\subsection{Power as a property of buyer-seller institutional arrangements}

Much research on business-to-business relations has been conducted from a perspective that suggests power is either a non-issue or is considered as being exclusively functional in: negotiations with suppliers when forming and reviewing contracts (Cho \& Chu, 1994); prices, costs, standards, choices, quality and strategies, payment methods and so on; or through compliance mechanisms and regulations (Hausman \& Johnston, 2010). However, studies show that buyers are also able to influence suppliers within and across industrial markets via other means. Some firms are able to do this through international arbitrage (Palmer, 2005), while others may induce significant changes in levels of competition by collectively mobilizing and confronting economic and institutional agents around a cause, a best practice or an innovative business model (Meehan \& Wright, 2007). Understanding this practice requires, according to Hingley (2005a, 2005b), an analysis which goes beyond the industrial economics definition, 
which focuses in the degree to which a firm influences market price (Wood, 1999), and towards one which considers how market actors are able to draw upon, interact with, institutions to influence social structures and practice.

Over several decades the Industrial Marketing and Purchasing (IMP) literature has drawn our attention to the enabling and constraining power of institutions in business-to-business exchanges (Ford, \& Rosson, 1982; Håkansson \& Snehota, 1995; Hingley, 2005a; Anderson et al, 2009). While there is a range definitions of institutions within the literature, most are concerned with, and reflect, the basic concern that institutions generate powerful regularity enabling, coordinating, and motivating or constraining behavior. North (1991: 97) defines institutions as the "humanly devised constraints that structure political, economic and social interaction." In North's broad definitional terms, institutions comprise both informal pressures (norms of behavior, conventions and self-imposed codes of conduct) as well as the formal pressures (rules, laws, constitutions). That is, actors will come to accept a shared sense of the social reality from the 'way things are' in buyer-seller relationships.

In the industrial marketing management field, studies have also shown in various ways how institutions shape the rules of exchange (Bello et al, 2004); structural market change dynamics (Hingley, 2005a), business network systems (Lindgreen \& Wynstra, 2005; Lukkari \& Parvinen, 2008), family institutional logics (Jansson, Johanson \& Ramström, 2007) and guanxi traditions and systems in emerging markets (Zhuang, Alex \& Tsang, 2010). This work brings out power as both an explicit and implicit property of institutions. Institutional structures and arrangements provide the power of stability, resilience, and endurance, and to resist challenges and challengers (Meyer \& Rowan, 1977; Jansson, Johanson \& Ramström, 2007; Hausman \& Johnston, 2010). Institutions therefore act as a stabilizer in buyer-seller relationships, whether buyer dominant, supplier dominant, independent or interdependent (Cox, 2004). More generally, the seminal contributions of DiMaggio and Powell (1983) and Meyer and Rowen (1977), together with a subsequent body of work in the management and sociological fields, explain the stabilizing 
properties of institutions why and how buyer-sellers grow more and more alike - that is, isomorphic. Critical in that respect, is the power of isomorphic mechanisms, including, coercion, attraction, mimesis and competition, for stabilizing, maintaining and ordering relationships. These are outlined in Table 1.

\section{*Insert Table 1 Here*}

Although these isomorphic mechanisms bring into view how the workings of the power is inextricably intertwined with, and involves, individuals and collective actors thinking institutionally and actively engaging in institutional work as part of business-to-business exchanges (Hingley, 2005a), institutional homogeneity and stability is not automatic or straightforward. Indeed, stemming from the initial work of Gaski (1984), a significant body of industrial marketing management literature has emerged, reporting on institutional instability and notably conflict in relation to marketing areas such as value co-creation, cooperation, dependence and competitiveness (Skarmeas, 2006; Fang, Chang, \& Peng, 2011; Mele, 2011; Zhou, Zhuang and Yip, 2007). Alongside this work, research on the value chain literature suggests a rather contested institutional homogenization practice (Robinson, 2009; Robinson, 2010a; Robinson, 2010b; Robinson, \& Rainbird, 2013). Taken together, this work shows varying degrees of instability from digitalization disruption, disintermediation, anti-leader market positioning and challengers, distrust and task and relational conflict. Therefore, institutional stability is not guaranteed or automatic and institutions must be transmitted over time, maintained on an ongoing basis to keep at bay challenges and challengers. To recognize the significance of institutional arrangements to maintain dominance in the face of external threats to privileged distribution channel positions, requires us to further understand the social micro venues at which actors engage in institutional maintenance work - the industrial supplier workshop. 


\subsection{Power as a property of industrial supplier workshops and institutional work}

Episodic events are widely employed to socially accomplish business-to-business interaction (Ford \& Hakansson, 2005). The relational buyer-seller interactive view constitutes a starting point for the identification of industrial workshops as venues in which actors identify, organize and order market actors to maintain stability within business exchanges. Hodgkinson et al. (2006) draws attention to social interactions at business workshops. Conceptually, here, industrial supplier workshops are framed as interactive institutional arrangements, situated within wider institutional industrial market conditions, where actors set aside typically one or two days, frequently off-site, to consider issues relating to the functioning of industrial markets. Through workshops, suppliers from various traditions can be further socialized in the routines, learn the cognitive and normative frames that shape their perspectives on regulative goals, and the likely means to achieve them. The industrial workshop thus can be understood as a mutual, although rarely equal, constituting institutional arrangement in which interdependent actors participate in, interact with, adapt to and/or shape institutional logics (Ford, Hakansson \& Johanson, 1986; Ford, Gadde, Hakansson \& Snehota, 2003).

The participation and role of culturally competent actors with strong practical skills and sensibility to navigate such institutional arrangements is therefore of significance in understanding power in business relationships (See Levy \& Scully, 2007). Institutional work an idea inspired and advanced by the work of Thomas Lawrence, Roy Suddaby and colleagues (Lawrence, Hardy \& Phillips, 2002; Lawrence \& Philips, 2004; Lawrence, Suddaby \& Leca, 2011) refers to all of the purposive action of individuals and organizations aimed at creating, maintaining, and disrupting institutional arrangements (Lawrence \& Suddaby, 2006). The concept of institutional work insists on the need to consider the permanent recursive and dialectical interaction between individuals (i.e. buyers, sellers) and institutions (Ford, Gadde,

Hakansson \& Snehota, 2003; Lawrence \& Suddaby, 2006). Lawrence \& Suddaby’s (2006) 
review describes a continuum of strategies for actors to engage in to maintain and reproduce institutional dominance. These range from that which has with high degree of awareness regarding its purpose and influence, such as enabling, policing and deterring practice, to that which is generally less comprehensible regarding norms and belief systems, such as valorizing/demonizing, mythologizing and embedding/routinizing practice, in routines and rituals of reproduction. This work provides a renewed focus on the social practice associated business to business interactions with institutionalization, rather than the traditional view of institutions as reified social structures with docile agents (Lawrence \& Phillips, 2004). Power is intertwined in the institutional work of the reciprocal role of actor links and resource ties and the interaction between organizations and within networks of relationships (Ford, Gadde, Hakansson \& Snehota, 2003).

Drawing on multiple conceptions of power as provided by a range of theorists - Hobbes, Weber, Machiavelli, Foucault, Gaventa and Lukes and others), Fleming \& Spicer (2007) complement this thinking on the institutional work, showing how the faces of power - manipulation, domination and subjectification - 'bear down' on institutional arrangements, actors and work. The manipulation of agendas in meetings and workshops through 'behind the scenes' politicking and talk, is a potential instrument of control, particularly for boundary spanning relations across the value chain. Talk is significant in the practice of power in that it permits speakers to monitor each other by observing one another (Goffman, 1979). In a series of significant work Bachrach \& Baratz (1962) argue that power is manifested not only through direct decisions but also through "the practice of limiting the scope of actual decision-making to 'safe' issues by manipulating community values, myths, and political institutions and procedures” (Bachrach \& Baratz, 1963: 632). There are various ways in which such non-decision practice can be enacted through, for example, a formal contract, compliance standards, quality control, an award ceremony, or an institutional script- a plan. While much is written about the destabilizing power practice in buyer-seller relationships (for example conflict), maintaining stability, arguably, 
requires behind the scenes skilled efforts and social practice (Lawerence \& Phillips, 2004).

Another practice of power is domination over the preferences and opinions of institutional actors. Domination is defined as 'the ability to bring about significant outcomes which will be present whenever it furthers, or does not harm, the interests of the powerful and bears negatively on the interests of those subject to it' (Lukes, 1974/2005: 86 cited in Fleming \& Spicer (2007: 20). This power assumes that organizational (non-) decision-making is not the sole aim or exercise of power, but it can be deployed to shape preferences, ways of life, attitudes, political outlook and broader social structures of community. Here, domination is enacted through the uncontested and unquestioned ground rules that are continually reaffirmed from 'a bedrock reality or anchor criteria’ (eg. sales and profit metrics, customer wants and needs, productivity indicators, local community engagement).

A final face of power as outlined by Fleming \& Spicer (2007) entails subjectification, whereby actors are constituted as subjects with certain understandings of themselves and the world around them. Subjectification is embodied in the idea that power is achieved through defining the conditions of possibility, thus underlying how individuals can be themselves. Rather than flowing from hierarchical centers of domination, the practice of power is individualized (Knights \& Willmott, 1989). In particular, Faucault's (1977: 194) work advances the idea that subjectification is produced through the technologies-of-the-self which are constitutive of 'surveillance' (the constitution of the self through every perception, every judgement and every act), 'examination' (the constitution of the self as an object that can be measured) and 'confession' (the constitution of the self as a subject that can be verbalized, judged and improved). Under the panoptic gaze, a supplier "becomes the principle of his own subjection" (Faucault's (1977: 202-203). This theoretical synthesis poses interesting questions as to what extent are the workings of power intertwined with institutional work, specifically micro-social supplier workshops, in the functioning of industrial markets? To what extent are the different 
isomorphic mechanisms and associated forms of power (manipulation, domination or subjectification) used in an industrial workshop setting?

The next section introduces the setting of the study - industrial sector and the workshop context - and then provides a brief account of our methodology in order to address these questions.

\section{Methodology}

This study explores the power dynamics of the institutional maintenance work at an industrial supplier workshop. In the following paragraphs we describe the institutional workshop setting and sampling process, the different data collection techniques, which were undertaken in the development of this study.

\subsection{Institutional Setting and Sampling}

Industrial Sector and Retail Co Case firm - The study was set in the context of retailer-supplier relational dynamics (Hingley, 2005a). Adopting a case study approach, we focused on one case involving an industrial supplier workshop led by Retail Co and held in specific a region of the UK. We followed Lincoln and Guba's (1985) guidelines for 'purposeful sampling' in choosing the industrial sector and the main case study. This practice relies on the case study being an example of the phenomenon under investigation to deepen our understanding with the accumulation of fresh observations (Tsoukas 2009 refers to this process as analytical refinement). Retail Co was judged to be most theoretical relevant for our main research questions: How is power intertwined with institutional maintenance work, specifically supplier workshops, in the functioning of industrial markets? To what extent are the different isomorphic mechanisms and associated forms of power used in an industrial workshop setting? Then we used a snowball technique within the industrial workshop, asking each informant for his or her recommendations as to who could best discuss the topic of interest at the workshop.

The case study workshop - This workshop took place in Edinburgh, Scotland during 2011. Retail Co proposed the venue and time and the workshop was attended by 120 suppliers from the 
Scotland region. At the time of the study, this represented 77 percent of the total population of Retail Co’s suppliers in that region. The workshop programme was entitled "Retail Co Scottish Supplier Conference: Improve your business by discovering how to be more effective in working with Retail Co and how to make your products stand out from the competition”. It began at $10.15 \mathrm{am}$ and closed at 15.30pm, lasting four and half-hours excluding forty-five minutes for lunch. The previous workshop had been held in 2009. The workshop was structured in three sessions, significantly around Retail Co’s core business principles covering customers, community, operations, people and finance. The first part of the workshop provided an update report on three parts of the core business principles - customer, community and people. The Category Technical Manager and the regional Marketing Manager undertook this. The second stage comprised an update on financial performance and operational issues from the Senior Regional Buying Manager. The third stage comprised a presentation on the use of marketing intelligence (MI), delivered by an external speaker, and the workshop concluded with breakout sessions during which participants were able to explore the use of MI in the context of their own businesses.

\subsection{Data Collection}

The case study workshop - Corley \& Gioia (2004) note that most social groups try to maintain an aura of stability; thus getting actors to talk about the complex social aspects of power dynamics can be difficult-to-access. To aid in understanding of the role of power in an industrial workshop, then, an ethnographic approach was adopted (See Hoholm, \& Araujo, 2011 for an overview of this approach in industrial marketing research). Here, the researchers' overtly and covertly, participated in the industrial workshop, watched what happened, listened to what is said, and generally collected whatever data could throw light on the informal and inconspicuous (i.e. norms of behavior, conventions and self-imposed codes of conduct) as well as the more, formal and visible (i.e. rules of engagement, compliance rules) aspects of the institutional workings of power. This ethnographic approach was enacted through four data collection techniques: (i) observation, (ii) documentation (namely Retail Co’s Powerpoint presentation 
material and a flipchart), (iii) convergent interviews, and (iv) informal interactions and casual conversations. Following Corley \& Gioia’s (2004) design approach, we replied primarily on observation, documentation and convergent interviews, with the other data serving as supplementary sources for understanding the research questions.

Observation. For this, we relied mainly on two of the researchers following an 'etic' or 'outsiders' view, while another researcher followed an overt, 'emic' or insider view, which involved actively participating in the workshop events. Our observational lens used a combination of Garfinkel’s ‘ethnomethodology’ and Pettigrew’s (1989) ‘extreme approach’ as clear points of data collection. On the one hand, Garfinkel's ethnomethodological aimed to reveal, describe, elucidate and explicate ‘familiar organisational things’ (Fox, 2008), affording them the attention usually reserved to extraordinary events. On the other hand, Pettigrew (1989) suggests that researchers should identify extreme situations and critical incidents, which were transparently observable.

Documentation. We collected unobtrusive data through documents pertaining to the industrial supplier workshop (Orlikowski \& Yates, 1994; Lawrence \& Suddaby, 2006). These documents took two forms: (i) a flip chart artifact with post-it note feedback. (ii) Retail Co’s PowerPoint artifacts. Regarding the material (non-human) artifacts, we specifically adopted Orlikowski \& Yates’ (1994) approach that acknowledges these as potential sites of institutional work; that is, the artifact is not only treated as physical 'containers' of knowledge but are understood broadly as a relational terms, actants imbued with meaning and which speak with, by, through and as entities (Lawrence \& Suddaby, 2006). Figure 1 (Flip chart) \& Figure 2 (PowerPoint slide) are thus illustrative of workshop artifacts, both of which proved helpful entry point devices for openended questioning- for example, did you write a question or comment on the flip chart notice board?

\section{*Insert Figure 1 Here*}


Convergent interviews. We conducted convergent interviews during the industrial workshop, accumulating a total of seventeen interviews (Perry, 1998). The interviews ranged from five minutes to twenty minutes in length. The researchers employed a convergent and divergent interviewing technique or 'convergent interviewing' (Dick, 1990 cited in Perry, 1998). In short, it is technique, which allows the researcher to develop, clarify, verify and refine the core issues under investigation in both a structured and unstructured way (Perry, 1998). During the early stages of the industrial workshop the interview was unstructured and flexible, although it became more structured as the interviewer converged with specific issues of the research problem and to disprove the emerging explanations of the data. Therefore initial interviews started with an openended question, did you write a question or comment on the flip chart notice board? This was then followed with another open-ended 'tell me about your experiences' statement in relation to the supplier workshop. We asked all informants to speak as the representative voice of the individual supplier and then as the collective voice of the supply-base at the workshop. Subsequent interviewing became progressively more semi-structured as themes emerged in the data, with the workshop participants focused on the following questions; Why did you attend the workshop? What were your expectations for the workshop? What are the dynamics of the different interests and priorities at the workshop? How do suppliers participate at the workshop? What is the work of this workshop? What does Retail Co do? To maintain consistency, the two lead authors conducted all interviews and compared notes throughout the day, with subsequent questions focused on categories and themes represented in our emerging data structure.

The data collected through interviews were supplemented by a much larger number of informal interactions and casual conversations during and in-between coffee breaks and lunch breaks. It was important that we also captured the 'off piste' parts of the workshop- in the breaks (3 fifteen minute breaks), over lunch, in the hotel corridors, lobby and outside in the courtyard. These periods were used proactively to elicit the views of the suppliers at the workshop. Both researchers talked with a total of twenty-seven suppliers and the three Retail Co actors. 
Whenever possible these interactions were recorded in hand written notes that enriched the data set.

\subsection{Data analysis approach}

With regard to the analysis of ethnographic data, this involved the search for ideas, patterns, and explanations, taking into consideration that language was "perhaps the primary medium of social control and power” (Fairclough, 1989: 3). In that respect, we identified a series of categories and instances within the data by desegregating the text (observation notes, PowerPoint presentation and in-depth interviews) into a series of fragments, which were iteratively regrouped under a set of thematic headings (i.e. signaling and speaking as the dominant, a disciplined space and compliance standards). For ethnographic analysis, comprehension is thought to be complete when the researchers can describe the events, incidents and exceptions from an emic perspective (Morse, 1994). Synthesis, involves coding and pooling the data and then constructing category links. We constructed a narrative of our findings from a combination of our observational field notes, interviews and documents. For the purpose of data presentation, our ethnographic analysis was developed beyond the level of 'thick description', which relates to the actual perceptions of participants, not least because the analytical phase of theorizing is seldom treated as a separate level with a distinct purpose (Morse, 1994). Finally, recontextualisation is achieved by forcing the theory to a level of abstraction, the degree of which determines the generalizability of the theory.

Four forms of verification were used in the analysis. First, when iteratively regrouping under a set of thematic headings, to help prevent our informants from becoming sensitized to Retail Co power via our interviews, we asked questions related to power only after the informant raised such issues. Second, we recycled between theoretical frames of reference developed by several studies (Goffman, 1967; Garfinkel 1957; Lawrence \& Suddaby, 2006; Orlikowski 2007). Insights from these studies allowed us to consider how workshop participants perceived and understood the workings of power in institutional dynamics. Third, the ethnographic analysis 
combined insider views and an outsider view to provide deeper insights than would be only possible from the 'natives' alone. Corley \& Gioia's (2004) term this 'peer debriefing', which entails the field researcher engaging other researchers not involved in the study to discuss emerging patterns in the data. We also triangulated this multi-sided view with the main observation data, the convergent interview data, and the documentation material and supplemented it with notes from the informal interactions, gathered during the workshop. Fourth, extending Corley \& Gioia’s (2004) notion of 'peer debriefing', the researchers used a reflective whiteboard exercise to serve as a sounding board for emerging issues from the industrial workshop, and to elicit critical questions from the supplier participants at the end of the workshop. Finally, we triangulated our individual case analysis, with evidence from subsequent workshops held by Retail Co in other regions across the UK supply chain (i.e. Belfast, Peterborough, Cardiff, Warrington and York). Only one of the researchers was present at these workshops, in his capacity as external expert and facilitator of the third session of the workshop on the use of MI. The insights he gained were captured in the form or written notes, made during the workshop (in the case of observations) and after the workshop (in the case of the informal discussions held at various times during the day). This precluded the use of (more formal) convergent interviews but nevertheless meant that observations could be made and informal interactions used to cover most of the questions posed during the main case study workshop, albeit on a smaller scale. However, the on-going relationship that this researcher had with many of the suppliers, with whom he had shared MI over many years, made it easier for him to approach suppliers and talk candidly about their relationship with Retail Co., the effectiveness of the workshop setting for organizational and personal learning and relationship development and its impact on their business. Through de-briefing sessions the research team compared notes and looked for corroborating evidence from these workshops to support their findings from the case study workshop. This subsequent feedback enhanced the interrogation and the presentation of the data from the case study workshop (Morse, 1994).

In summary then the research stages were administered consecutively. The triangulation 
approach taken, epistemologically, was to understand meaning and develop a range of categorizations on the rhetorical strategies. The next section presents the findings derived from them.

\section{Research Findings}

What follows is a description of the findings pertinent to the aim of this study presented. The findings presented are primarily concerned with the case study workshop.

\subsection{Signaling and speaking as 'the dominant'}

The welcoming introduction of the workshop enabled us to develop a basis for observing how Retail Co sought to immediately construct its own identity relationally to the cluster of suppliers it had gathered. The observations shed light on Retail Co’s practice of signaling and speaking as the dominant actor. First, Retail Co sought to project itself and to reinforce marketplace legitimacy. Posing the rhetorical question "Where can I go?”, Retail Co successfully drew on a system of numbers to confer certainty and attraction on its perspective. Here, Retail Co engaged with the 'talk' and language of numbers to establish unquestioned authority and indeed attraction (the performance numbers were aesthetically attractive). The conception of these facts as epideictic rhetoric was closed to discussion - an uncontested signal of the dominant. In the deployment of epideictic rhetoric Retail Co assumed 'rationality' - that everyone with the same training, qualifications, and information would reach the same conclusions. By implication the PowerPoint artifact immediately brought into sharp focus supplier insecurity and uncertainty about the relativity of position when working with the dominant. The speakers also appealed to, and drew reference from, mythologizing the "legacy of the former CEO" [of Retail Co], developing the strategic direction. Other related points surfaced during our early interviews: 'Retail Co were peacocking alpha style' (Supplier Interview 9) and the industrial supplier workshop became a Lek space where suppliers positioned themselves not only to see, but to be seen. As one interviewee put it, "If I want to move from a regional to a national supplier; I need to be seen at these events; I need to be seen to be listening to ...[Retail Co's]... agenda and then 
conforming." (Supplier Interview 5). The dominance of Retail Co. was less pronounced in the workshops held by Retail Co in other regions across the UK. The smaller numbers and less formal settings of the chosen venues created 'a greater sense of intimacy' and community that was lacking in the main case workshop. However, it was no less clear to everyone involved where the power was located and the informal conversations, during and after events, revealed very similar motivations for attending and very similar perceptions of the stage that Retail Co. created to communicate its message rather than listen as were found in the main case workshop.

Second, the language of dominance was signaled via a PowerPoint presentation as a form of a game - entitled "The Heads and Tails Game" - an activity, which falls under what Elgood (1989) terms 'progressive games'. Fourteen questions were presented to suppliers, each with two answer options; heads or tails. Those suppliers that correctly answered the questions would remain standing. The questions were based on numerical performance metrics about 'Retail Co', comprising topics such as the number of stores owned by 'Retail Co'; turnover; the sales of Scottish products in the last year; the market share of 'Retail Co' in Scotland; specific questions regarding local produce, including purchase data for local produce, visits to the local website; and how 'Retail Co' compared to other major multiples in terms of consumers attitudes to local produce in Scotland. All of the answers conferred Retail Co's market legitimacy as well as size selecting the largest number from each answer resulted in a 100 percent score. By beginning the workshop with a game, Retail Co not only signaled the potential opportunities of the association and membership with Retail Co's business listing, but also the performance meanings attached to that membership.

Another dimension of this phase of the industrial workshop was an Awards Ceremony, whereby five suppliers were congratulated for 'best practice' supplier initiatives when working with Retail Co. Within the industrial workshop, organizing and instituting the market rules depends on a repertoire of moves to sell issues and affect top- level decision makers' attention. During the interviews, the suppliers seemed quite sure that the process of exhibiting 'best practice' of other 
suppliers signaled a code of "what does and does not work when working with [Retail Co]" (Supplier Interview 2). While other suppliers suggested that it symbolically recognized and created an impression of an aspirational upward movement and identity for certain members. In one interview, a supplier reflected on this: "The opening workshop ways and moves were about how to find favour with Retail Co. That's the expectation.”(Supplier Interview 11). From our observations, the opening moves had framed success - and rewarded those that had engaged and changed - and implicitly appealed to the other suppliers to make similar moves. Another supplier noted: "In our experience, discipline is the necessary price for realizing market opportunity access. Getting through that Gatekeeper requires a type of affiliated knowing and that gets to the heart of it. In effect it's a stick-with-us-and-you-will-go-places logic and mindset." (Supplier Interview, 18). Similar views were expressed at the workshops held by Retail Co in other regions across the UK, with an often begrudging recognition that without an affiliation with Retail Co. it would be difficult for ambitious local suppliers to grow their businesses. Opportunities to capture precious shelf space within Retail Co’s estate were acknowledged as rare and often referred to as 'golden opportunities not to be missed', suggesting that suppliers were willing to offer and keen to demonstrate their commitment to the cause.

Another related theme to emerge, revealed itself in the subsequent observed workshop proceedings - in effect these activities promoted 'a light and positive' atmosphere before moving towards the 'business end' of disciplining. Before joining the disciplinary agenda - that is, before commencing the institutional work of marshalling the suppliers with ideas in which compliance issues were ‘sold’ via Retail Co’s persuasive efforts. This observed positivity and drama soon gave way to an intensified disciplinary space.

\subsection{The intensification of a disciplined space}

The 'rules of engagement'. If the first task was to render Retail Co as the dominant actor, these sanguine interactions gave way to a disciplined space in which three strategic issues became the dominant concern to Retail Co. In triangulating the data, the disciplined space represented instances in which members recognized an inconsistency between the suppliers' current position 
and claims of what it would be or what Retail Co would like it to be in the future. As one supplier indicated, there was some apprehension during the break: “I anticipate we are going to be told what we need to do better - neither this coffee, or the lunch later, will be free. And, no doubt, Retail Co will be put down a further marker, to police and press for us for even more to ensure that there is no competitive slippage.” (Supplier Interview 4).

Following the coffee break, the rules of engagement as outlined in Figure 2, were outlined and interestingly framed by the Senior Scottish Buying Manager of Retail Co as soft and docile 'Key Principles', rather than hard business exchange rules. At the same time, we also observed that the tone and presentation changed. Retail Co outlined its ' supplier position', stating what actions it wanted all parties to carry out; and its 'fallback position', stating the unilateral action it would take if its position were rejected. The voice accompanying the PowerPoint slide detailing the rules caught suppliers' attention and produced a workshop arena buzz, as summarized by two suppliers in two different ways: "We have an issue of market access. How do I get attention? I attend workshops such as this one, but there is little opportunity for us to present our ideas as suppliers. It is all one way.” (Supplier Interview 10). "There is a strong emphasis on inclusivity and participation with the suppliers working more on the front margin rather than the back margin, on how we sell rather than how they buy. This produces coercion-attraction tensions and trade-offs."(Interview 11)

\section{*Insert Figure 2 Here*}

After the initial rules of engagement were outlined and reinforced explicitly, the institutional maintenance work turned to confronting suppliers with specific areas for compliance standard improvement. Significantly, the workshop became a calculable arena in which a normative imperative was driven by one strategic vision (Retail Co) and the associated epideictic rhetoric called upon the self-assessment of others (Suppliers). As one supplier explained, "I suppose there is a sense of unity and community here at the workshop - between the executives who come from diverse product offerings - because we are galvanized by amount of work and tasks that we face.” (Supplier Interview 16)

Confronting suppliers' compliance standards. The supplier workshop had moved significantly 
beyond the initial sanguine practice of the Category Technical Manager and the Local Marketing Manager, and towards a more strategic agenda driven by the Senior Scottish Buying Manager of Retail Co. Summarizing Figure 2, Senior Scottish Buying Manager commented: “...these are not something to be afraid of. It is simply a way of doing business with us." PowerPoint was used to outline the template for doing business with the firm - an uncontested, epideictic-based template, which formed the basis of the interaction with suppliers at the workshop. Further illustrative quotations associated with the rules of engagement are summarized in Table 2.

\section{*Insert Table 2 Here*}

The standardization compliance profession on Strategic Business Planning and Operations arguably set the tone for remaining parts of the workshop. In particular Retail Co sought to draw attention to, and promote, the institutional ideas of (i) the service levels into the store and (ii) store conformance. Standards of practice provide guidelines, norms and regulatory prescriptions relating to how that practice was to be carried out within some determinate institutional setting. Regarding the service levels into the store, again the Senior Scottish Buying Manager of Retail Co used the power of numbers to convey his idea. In calculative terms, he stated that “...742,000 cases were refused/rejected at the store level, averaging $£ 8$ per case and with an estimated sales loss of £5.9 million per annum. Regarding store conformance, he targeted a 1\% improvement and suggested that this could result in an additional 110.5 million in sales." The same calculations were made for the workshops held in the other regions and presented in exactly the same way as the case study workshop. The emphasis was very clearly on the benefits of compliance and the responsibility that suppliers should take for ensuring THEIR stock is in the right STORE at the right TIME at the right PRICE regardless of the systemic issues within Retail Co, which many suppliers believed were the primary cause of non-compliance. The case for compliance was presented very plainly as one of 'low hanging fruit' and suppliers were left feeling that their inability to pick it would no longer be tolerated.

We observed that the Buying Manager's projective institutional work focused on two selfregulatory standards of practice in particular. The first institutional projection sought to build affiliated knowing through Retail Co's information systems, which sought to produce a picture 
of what stores are ranged for supplier products, but not stacking it, and simultaneously reproduce those expectations. Here, Retail Co sought to delegate the idea of responsibility through for example store visits and store manager discussions. A second institutional projection targeted waste, which it was argued, was the biggest single reason for a store delisting a product (examples given were unit sizes being too large, incorrect code life, or the choice of stores, of which many suppliers were blissfully ignorant).

In practice, Retail Co did not act alone however. The Buying Manager’s projective institutional work was augmented with institutional complementary work from an academic institution, championing the adoption of customer insights from Market Intelligence (MI). The industrial workshop was a way of knowing how others gained insights into specific consumer niches, actual buying behaviors, how specific product categories are performing and how specific suppliers performed. Advocacy required the power of the cognitive legitimacy of the expert. Here, the expert from a complementary institution confronted suppliers to provide information and marketing intelligence that goes beyond that gathered, for example, by more traditional market research surveys. However, in so doing, he was also offering support, free of charge, thereby removing two of the obstacles to gaining (cost) and making use of (know-how) MI and providing Retail Co with a symbolic offer of support and the removal of any legitimate excuses for failing to use MI to support their marketing decision-making

\section{Discussion of Findings}

Framing the study of the industrial supplier workshop setting in this paper has provided new insights into the workings of power in business exchanges. In the following paragraphs we draw out a number of themes with theoretical implications, focusing particularly on how the institutional maintenance work is accomplished in the social venue of industrial supplier workshops.

\subsection{Industrial Workshops as Cultural Performance Work}

A substantive insight that we can take from this study of the industrial workshop concerns the relative influence of institutional pressures from cultural performance work (Elgood, 1989). Institutionally, this related to the normative pillar, which stipulates common ways of acting and 
behaving (Scott, 2001). It involved presenting Retail Co in a way that appealed to everybody (attractive and mimetic pressures). For the most part, the formative actions, interactions and gestures were not only directed at the suppliers attending the workshop to accept its motives and explanations as a reasonable account of the changing institutional field, but it appealed to a wider audience beyond those who have an immediate interest or vested stake in meta institutions (e.g. its contribution to the whole economy driving consumption-related growth) and micro institutions (e.g. the local economy, local social community groups). In another context, the practice of workshop power is strategically seen to be developing local supply bases and suppliers; seen to be sourcing ethically sourced products and seen to be conforming to good practice and the rational actor (Tunisini, Bocconcelli \& Pagano, 2011). That is, the power of institutional 'priming work' as both a signal and consequence of social embeddedness and control. The Local Marketing Manager as well as the Category Technical Manager for the Scotland region mainly undertook this work. In that period, Retail Co made available to others at the workshop an unambiguous signage and epideictic declaration in the power of numbers - we are successful; we are responsible; we are the leaders in our field; we are the dominant force and we are also an integral part of the local community (Denis, Langley \& Raileau, 2006). For suppliers, these communal, shared experiences serve as a basic and, fundamental need to belong. Thus, an analysis of subject positions, of membership, interactions, structures of domination, and information shared among actors, helps us to understand the institutional boundaries and the powerful principles of differentiation employed within those boundaries.

In industrial economic theoretical treatments of dominant firm practice, dominance is defined by two characteristics: possession of a cost advantage and ability to price as a Stackelberg leader. For example, empirical studies of dominant firms have identified dominance primarily by a firm's market share, with a share of forty or fifty percent used as the typical threshold for market dominance. Yet understanding the institutional maintenance work carried out by dominant actors to maintain market dominance in the face of external threats to their privileged position must theoretically expanded upon. Institutional maintenance work required Retail Co's identity development to be subject to inter-play between the features of a focal actor and the actor features of others (Håkansson et al., 2009). The convening authority of Retail Co is institutionally significant. In that practice, Retail Co harnessed suppliers' agency for them 'to be 
successful' and 'to achieve' by strengthening an 'aspirational identity' that insists suppliers continuously strive to be more prototypically conforming (Emirbayer \& Mische, 1998). Ostensibly, the industrial supplier workshop permitted an expressive 'network identity' with the findings capturing the duality of isomorphic power in relation to perceived attractiveness (market access, large, dominant), but also simultaneously, aspects of resentment (coercion, unilateral, determining) of a firm as an exchange partner and convening authority (Hingley, 2005a,b; Fleming \& Spicer, 2007).

The workshop reflected the contradiction of power at work. The first part provides the collective representations for cultural performance work; another part comprised the strategic utility agenda script. There is therefore more at play than economic stakes and/or coercion (Blois, 2005). The 'cultural priming work' with the performativity of the award ceremony providing Retail Co with a social setting and engine in which they could placate organizational norms and sooth contradictory tensions. We contribute here to industrial marketing literature that views power as performative and therefore intertwined in the practice of the institutional work of actors, when considering the reciprocal role of actor links and resource ties and the interaction between organizations and within networks of relationships (Ford, Hakansson \& Johanson, 1986; Ford, Gadde, Hakansson \& Snehota, 2003). The industrial supplier workshops were used to break down and bridge the discrepancies that separated Retail Co from its suppliers, promote and or restore goodwill and an image of a shared fate, thus extending Hausman, \& Johnston's (2010) work on the indirect mediating mechanisms that influence trust, commitment, and compliance in supply chains. Although cultural performance identity and political work provide a means for "supporting, repairing, or recreating the social mechanisms that ensure compliance" (Lawrence \& Suddaby 2006:230) and the formal and informal social basis on which an institution can be constructed, it does not however provide detailed models of how an institution functions. This requires technical work, relating to the cognitive-cultural pillar of institutions involving the construction of 'mental models' and projecting views of a shared world (Scott, 2001; Sahadev, 2005).

\subsection{Industrial Workshop as Projective Agency Work}


The institutional maintenance work in the industrial workshop reflected that associated with mobilizing thought leadership via 'projective agency' (Dorado, 2005), in stipulating, directing and appealing within of three agenda-setting issues and how these may be used how they may be used for legitimation or relegitimation of institutionalized supplier roles and expectations. Through 'cognitive anchoring' work, the dominant actor took the initiative by framing the future subtly but significantly, for the suppliers' own making. Institutional maintenance work thus involved 'the imaginative generation by actors of possible future trajectories of action, in which received structures of thought and action may be creatively reconfigured in relation to actors' hopes, fears, and desires for the future' (Emirbayer \& Mische, 1998: 971). Regarding the maintenance work, and extending Lawrence and Suddaby (2006) study, the findings link the literature on institutional work of enabling, policing, and deterring (Jia, Cai \&Xu, 2014; Yang \& Wang, 2011), with that of the Industrial Marketing and Purchasing (IMP) Group (Ford, Gadde, Håkansson, Snehota, \& Waluszewski, 2008; Meehan \& Wright, 2012; Peters, Pressey, Vanharanta, \& Johnson, 2013), through the interactive role of work of agency and maintaining power in the supply chain world envisaged by Retail Co.

The PowerPoint presentation imagined trajectories for business planning, operations and market intelligence and provided the 'content' for repairing, where appropriate, processes, therefore stabilizing dominant institutional market logics. This contributes to industrial marketing management literature, providing insights into the forces of institutional instability; specifically the institutional conditions for producing relational tensions and conflict in areas such as missions, goals, value co-creation, cooperation, dependence and competitiveness (e.g. Hingley, 2005a; Kumar, 2005; Fang, Chang, \& Peng, 2011; Zhou, Zhuang and Yip, 2007). In Dorado’s (2005) terms, the industrial workshop represented a form of 'convening' and bringing together a set of suppliers with many and varied vested interests to exert authority, set agendas, frame arguments (Fligstein, 2008). As well as undertaking cultural performance identity work, the activities of Retail Co also suggest forms of political institutional work. Specifically, Retail Co sought to reaffirm standard compliance rules within the wider social knowledge system of doing business with the firm (e.g. the Core Business Principles) and agency with the social position of the Senior Scottish Buying Manager of Retail Co. Most of the regulative pillar maintenance work of institutions (Scott, 2001), such as advocating a practice to other actors through direct 
social suasion, defining boundaries between who is inside and outside the social system, and vesting certain interested actors with specific roles and rights (Lawrence \& Suddaby, 2006) was therefore undertaken by the Senior Buying Manager. During the workshop much of the technical crafting work was undertaken by the Buying Manager, while also, and significantly, drawing and building links between Retail Co’s technical work and that provided by a 'pressure specialist' (Lipsky, 1980) from an academic institution. The role of the 'pressure specialist' along with institutional complementarity (Hall \& Soskice 2001) gave Retail Co a degree of social cognitive legitimacy with the university actor's expert power (Sahader, 2005) making the argument more efficacious, not least because the university actor was 'detached' from Retail Co. Institutional complementarities, then, were reinforced by the institutional actor presence and also involvement at the workshop.

\subsection{Industrial Workshop as Power Intensification Work}

The findings provide insights into the multi-dimensional workings of power in the industrial workshop, with the intensification of 'power over', 'power to', and 'power with' germane to the analysis of industrial workshop. In maintenance work, our study shows that Retail Co not only enforced its views or desires onto suppliers ('hard power'), but it also highlights the role of 'soft power'. Critical to this 'soft power' had been power intensification (Hardy \& Thomas, 2014) to increase supplier docility and utility with the epideictic discourses of projective compliance and an affiliated way of knowing and a system of knowledge, without necessarily being seen to be disciplinarian in the instituting and normalizing of distinct in-group market rules. To understand this institutional work, we find that Knights \& Willmott's (1989) notion of the voluntary technologies of the self at play- that is, with self-examination and 'calculative' assessments via the maintenance of 'the rules of engagement' for enhancing business planning, operations and market decision-making practice. The industrial workshop produced an unremitting gaze of self-inspection and a constant comparison with peer suppliers (isomorphic competition) from the social and interrogatory conditions of the workshop apparatus. In addition, the suppliers were subject to Retail Co's epideictic discourse that limited, defined and normalized their vocabularies of motive (Lawerance \& Suddaby, 2006), making sensible and accountable what suppliers 'should do, can do and thus do' (Clegg, 1989). This builds on and extends insights that have been developed in the relational view within industrial 
marketing literature, around the preference for stable, predictable and ordered business-tobusiness relationships (Håkansson \& Snehota, 1995; Kumar, 1995; Lukkari \& Pervinen, 2008; Munksgaard, 2010). It also builds on the work of Huemer (2004) and Bachrach \& Baratz's (1962) notion of non-decision making by setting the industrial workshop agenda, which can be used to reinforce stability, to maintain the dominant logic and to legitimatize the social market structures. Through discourses of the self, Retail Co harnessed the practice of peer assessment (e.g. award ceremonies, listing compliance), benchmarked joint planning initiatives (Key Performance Indicators, product support, policy to manage overstocks), rankings on their performance management systems from sales performance data on categories and products within in each store. The distinctions between 'power over', 'power to', and 'power with' therefore serve to allow for the fluid switching from hard power to soft power, and perhaps from conflict to cooperation, as the relationships between the dominant actor and its suppliers evolve, and also as the institutional conditions permit.

\section{Conclusions and Future Research Directions}

This paper attempts to understand the power dynamics in an industrial supplier workshop setting. The study of the industrial supplier workshop yields insights into how an industry leader socially accomplishes and maintains institutional dominance in a business-to-business field. We identify three important workings of power in the industrial workshop - cultural performance, projective agency work and the intensification of power. Taken together this practice directed the instituting of distinct market rules and enhances specific strategic agendas and vested interests in business planning, operations and market decision-making practice. This provides us with a useful way of understanding institutional arrangements and work in maintaining power. As the work of the industrial workshop suggests, institutional maintenance involves considerable effort and work to respond to potentially threatening environmental change from suppliers and other competitors. Far from acting in a docile manner, Retail Co purposefully used the workshop to shape the institutional logics that legitimatize the social structures of its market. We show that in buyerseller exchanges, there are constraints on practice from the pervasive but largely invisible disciplinary processes to which suppliers are subjected, where power is embedded in the institutional structures and practice to secure cooperation. 


\subsection{Limitations and future research developments}

The nature of ethnography implies that the researcher is part of the field that is under study and consequently this limits its ability to generalize beyond the sample of one industrial supplier workshop. Related to this the focus on one sector (food retail sector) and one geographic region (Scotland, UK), albeit with insights from workshops held in other UK regions, also limits the ability of this study to provide generalized results. However, our case study of the industrial workshop is an example of the phenomenon under investigation. It sought analytical generalizability where data is generalized to a theory, not to a sample (Pratt, 2008). The case study industrial workshop therefore represents only a 'slice' of time and context. Future work looking to generalize the findings requires a focus on sectors that can produce a basis for comparison and further development of the institutional work in industrial workshops.

The industrial workshop is theory-in-progress and further research and theoretical elaboration are required. A particularly notable feature of this study is the social skills associated with institutional work (Lawrence \& Suddaby, 2006: 214). As this study shows, the work of maintaining dominant institutions requires some degree of agency and when and how this work occurs at industrial workshops requires more examination. Of particular interest to further study are the complementarities between institutions located in different spheres of the market and the ways in which those might disrupt the power dynamics. Researching the workings of power from those firms seeking to disrupt or create alternative institutions might be a useful avenue. For market challengers, and lower status institutions, workshops become an important medium for firms to think, do and articulate the unthinkable. Understanding the counter-claims and accusations, contestations and the competing visions, anti-leader positioning and rivalries, tensions and conflicts, against the uncontested epideictic rhetoric might allow us to further understand the ways that market leaders attempt to defend 'their market' and the dominant status quo in the face of challengers, contests and deinstitutionalism.

In practice, we observed an emphasis placed on institutional maintenance work and strengthening the linkage between sales and buying, as well as market intelligence, operations and planning at the workshop. These interconnections would provide an interesting area to study. 
Moreover, the extent to which institutional maintenance work is more important at the market periphery remains an important boundary condition for future studies. Although this study focuses on the institutional work of Retail Co with regard to one episodic supplier interaction, this study nonetheless overlooks other micro-social workshops and meetings whereby Retail Co liaises with other actors such as regulators (for example, Competition Commission and lobby work to change the legislative framework and rules in its favor). The practice of power therefore is multi-faceted, comprising multiple institutions, actors and languages (Clegg, 2010), and more research is required in this area.

Developing a broader, institutional perspective on power within a highly institutionalized business system and institutional stability, also raises questions regarding instability where digital disruption via the Internet creates new power dynamics; with those seeking to lesson dependency through building countervailing power (e.g. through cooperative arrangements and quality assurance branding initiative setting). Only a modest amount of research has begun to examine the role of actors in maintaining institutions over time and the associated power dynamics (Blanc \& Huault, 2014). Equally, regarding an understanding of the power of industrial market conditions that is more heterogeneous and fragmented. These remain underexplored in the current paper, but industrial workshop studies undertaking in different business systems and industrial markets is worthy of more research.

\subsection{Managerial Implications}

Maintaining institutional stability and workshop organizing are complementary practices. Industrial workshops are often seen as exclusive venues for path creation; to share new ideas, agendas or initiatives with suppliers. Yet, from our case analysis, the organization of the workshop is a social accomplishment involving a greater variety of institutional work than is generally understood. From this practice, institutional stabilizing co-evolves with organizing work. Rather than acting in a docile manner, this actively requires institutional work to maintain and reinforce the informal (norms of behavior, conventions and self-imposed codes of conduct) as well as the formal (product listing, category compliance rules). Also noteworthy in this respect is the role of workshop dramaturgy - fictionalized representation of games, ceremonial awards and this is complementary to the competitive disciplining of a supplier workshop. How to 
constitute and mobilize suppliers thus requires a mixture of initiatives that ease competitive tensions, while also creating an aspirational identity supplier condition. The practice of power soothes and enables the institutional work order conditions and social participation in the structures of industrial business exchanges. Related to the second point, in some key respects, not only should the workshop become more dramaturgical-orientated, but also there is perhaps an opportunity for more mediated episodes to build reciprocal value propositions and consonance amongst other suppliers. An industrial workshop approach ensures, moreover, the mediation between action and cognition through ongoing talk. One could also caution that, one annual workshop would never solve the day-to-day antagonism debates with any dominant buyer, yet the supplier workshop venue has the potential to break down and break up old structures - and with it, entrenched power structures. For those suppliers questioning their participation at such workshops, the study offers fascinating examples of small interventions on costs and compliance standards, delivery pace, wastage, reverse logistics and supplier-buyer effort bargaining, amongst others, with potentially big implications for the 'rules of engagement' with the dominant buyer. There is therefore much to be gained from workshop inclusion and participation. 


\section{REFERENCES}

Andersen, P.H. Christensen, P.R. \& Damgaard, T. (2009). Diverging expectations in buyerseller relationships: Institutional contexts and relationship norms, Industrial Marketing Management, 38 (7), 814-824.

Bachrach, P. \& Baratz, M.S. (1962) Two Faces of Power, The American Political Science Review, 56 (4), 947-952

Bello, D.C., Lohtia, R., \& Sangtani, V. (2004). An institutional analysis of supply chain innovations in global marketing channels. Industrial Marketing Management, 33 (1), 57-64.

Blanc,A., \& Huault, I. (2014). Against the digital revolution? Institutional maintenance and artefacts within the French recorded music industry. Technological Forecasting and Social Change, 83, 10-23.

Blois, K. (2005). Self-interest and not benign power-a comment on Hingley's Power to all our Friends, Industrial Marketing Management, 34 (8), 859-862.

Blois, K. \& Hopkinson, G. (2013). The Use (and Abuse) of French and Raven in the Channels Literature, Journal of Marketing Management, forthcoming.

Bourdieu, P. (1977). Outline of a theory of practice. Cambridge: Cambridge University Press.

Caniëls, M.C.J. \& Gelderman, C. J. (2007). Power and interdependence in buyer supplier relationships: A purchasing portfolio approach. Industrial Marketing Management, 36 (2), 219229.

Clegg, S., (1987). The Power of Language, the Language of Power. Organization Studies, 8, 6070.

Clegg, S., (1989). Frameworks of Power. London: Sage.

Clegg, S. (2010). The State, Power, and Agency: Missing in Action in Institutional Theory? Journal of Management Inquiry, 19 (4), 4-13.

Corley, K.G. \& Gioia, D, A. (2004). Identity Ambiguity and Change in the Wake of a Corporate Spin-Off, Administrative Science Quarterly, 49, (2): 173-208.

Cho, D-S, \& Chu. W. (1994). Determinants of bargaining power in OEM negotiations. Industrial Marketing Management, 23 (4), 343-355.

Denis, J.L., Langley, A. \& Rouleau, L. (2006). The Power of Numbers in Strategising, Strategic 
Organization. 4 (4), 349-377.

DiMaggio, P. \& Powell, W.W. (1983). The iron case revisited: institutional isomorphism and collective rationality in organizational fields. American Sociological Review, 48, 147-160.

Dorado, S. (2005). Institutional Entrepreneurship, Partaking, and convening.

Organization Studies, 26 (3), 383-413.

Elgood, C. (1989). Handbook of Management Games, $4^{\text {th }}$ Edition, Gower Publishing, Aldershot. Emirbayer, M. \& Mische, A. (1998). What Is Agency? American Journal of Sociology, 103, 4, 962-1023.

Fairclough, N. (1989). Language and power. Longman, London.

Fang, S., Chang, Y., \& Peng, Y. (2011). “Dark side of relationships: A tensions-based view,” Industrial Marketing Management, 40(5), 774-784.

Fleming, P. \& Spicer, A. (2007). Contesting the corporation, struggle, power and resistance in organizations. Cambridge University Press.

Fligstein, N. (2008). Fields, power, and social skill: A critical analysis of the New Institutionalisms. International Public Management Review,9: 227-252.

Ford, D., \& Rosson, P. (1982). Manufacturers-overseas distributor relations and export performance, Journal of International Business Studies, 13(Fall), 57-72.

Ford, D., Gadde, L.E., Hakansson, H., \& Snehota, I. (2003). Managing business relationships, (2nd edn), Chichester: Wiley.

Ford, D., \& Hakansson, H. (2005). The idea of business interaction, The IMP Journal, 1(1), 427.

Fox, S. (2008). That miracle of familiar organizational things: Social and moral order in the MBA classroom, Organization Studies, 29. 737-761.

Gaski, J. (1984). “The theory of power and conflict in channels of distribution,” Journal of Marketing, 48(3), 9-29.

Garfinkel, H. (1967). Studies in ethnomethodology. Englewood Cliffs, New Jersey.

Goffman, E. (1959). The presentation of the self in everyday life. Doubleday. New York. Håkansson, H. (1982) International marketing and purchasing of industrial goods, John Wiley and Sons, Chichester 
Håkansson, H., \& Ford, D. (2002).How should companies interact in business networks. Journal of Business Research,55(2), 133-139.

Håkansson, H., Ford, D., Gadde, L. -E., Snehota, S., \& Waluszewski, A. Håkansson, H., \& Snehota, I. (1995). Developing relationships in business networks. London:Routledge.

Hall, P.H. \& Soskice, D. (2001) Varieties of Capitalism. The Institutional Foundations of Comparative Advantage. Oxford University Press, Oxford:

Hardy, C. \& Thomas,R. (2014). Strategy, discourse and practice: The intensification of power. Journal of Management Studies, 51(2), 320-248.

Hausman, A. \& Johnston, W.J. (2010). The impact of coercive and non-coercive forms of influence on trust, commitment, and compliance in supply chains. Industrial Marketing Management, 39 (3), 519-526.

Hingley, M.K. (2005a). Power to all our friends? Living with imbalance in supplier-retailer relationships, Industrial Marketing Management, 34, 848-858.

Hingley, M. (2005b). Response to comments on 'Power to all our Friends? Living with imbalance in supplier-retailer relationships, Industrial Marketing Management, 34 (8), 870-875.

Hodgkinson, G.P., Whittington, R., Johnson, G. \& Schwarz, M. (2006). The Role of Strategy Workshops in Strategy Development Processes: Formality, Communication, Co-ordination and inclusion, Long Range Planning, 39, 479-496.

Hoholm, T. \& Araujo, L (2011) Studying innovation processes in real-time: The promises and challenges of ethnography, Industrial Marketing Management, 40, 6, 933-939

Hopkinson, G. \& Bois, K. (2013). Power base research in marketing channels: a narrative review, International Journal of Management Reviews.

Huemer, L. (2004).Balancing between stability and variety: Identity and trust trade-offs in networks. Industrial Marketing Management,33(3), 251-259.

Hu, T-L. \& Jiuh-Biing Sheu, J-B. (2005). Relationships of channel power, noncoercive influence strategies, climate, and solidarity: A real case study of the Taiwanese PDA industry, Industrial Marketing Management, 34 (5), 447-461.

Jansson, H. Johanson,M. \& Ramström, J.(2007). Institutions and business networks: A comparative analysis of the Chinese, Russian, and West European markets, Industrial Marketing Management, 36, (7), 955-967. 
Jarzabkowski, P. Balogun, J. \& Seidl, D. (2007). Strategizing: the challenges of practice perspective, Human relations, 60(1), 5-27.

Knights, D., \& Willmott, H. (1989). Power and subjectivity at work: From degradation to subjugation in social relations. Sociology, 23, 535-558.

Kumar, N. (2005). The power of power in supplier-retailer relationships. Industrial Marketing Management, 34 (8), 863-866.

Lawrence, T. B., \& Suddaby, R. (2006). Institutions and institutional work. In S. R. Clegg, C. Hardy, T. B. Lawrence, \&W. R. Nord (Eds.), Handbook of organization studies (2nd ed.). Sage. London.

Lawrence, T. Suddaby, R. \& Leca, B. (2011). Institutional Work: Refocusing Institutional Studies of Organization, Journal of Management Inquiry, 20(1) 52-58.

Lawrence, T.B., Hardy, C., \& Phillips, N. (2002). Institutional effects of interorganizational collaboration: The emergence of proto-institutions. Academy of Management Journal, 45, 281290.

Lawrence, T. B., \& Phillips, N. (2004). From Moby Dick to Free Willy: Macro-cultural discourse and institutional entrepreneurship in emerging institutional fields. Organization, 11(5): 689-711.

Lawrence, T. B., Winn, M. I., \& Jennings, P. D. (2001) The temporal dynamics of institutionalization. Academy of Management Review, 26: 624-644.

Lincoln, Y, \& Guba, E. (1985). Naturalistic inquiry. Newbury Park, CA: Sage.

Lindgreen, A. \& Wynstra, F. (2005). Value in business markets: What do we know? Where are we going?, Industrial Marketing Management, 34(7), 732-748.

Lipsky, M. (1980). Street-Level Bureaucracy: Dilemmas of the individual in public services, Russell Sage Foundation, New York.

Lukkari, P. \& Parvinen, P. (2008). Pharmaceutical marketing through the customer portfolio: Institutional influence and adaptation. Industrial Marketing Management, 37 (8), 965-976.

Mason, K. \& Spring, M. (2011). The sites and practices of business models, Industrial Marketing Management, 40 (6), 1032-1041.

Meehan, J. \& Wright, G.H. (2012).The origins of power in buyer-seller relationships. Industrial Marketing Management, 41 (4), 669-679. 
Mele, C. (2011). “Conflict and value co-creation in project networks,” Industrial Marketing Management, 40(8), 1377-1385.

Meyer, J.W. \& Rowan, B. (1977). Institutional organizations: formal structure as myth and ceremony, American Journal of Sociology, 83, 340-363.

Morse, J.M. (1994), “Emerging from the data: the cognitive process of analysis in qualitative enquiry”, in Morse, J.M. (Ed.), Critical Issues in Qualitative Research Methods, Sage, Thousand Oaks, CA.

Munksgaard, K. B. (2010). Exploring perceptions of interdependencies: Strategic options in supplier-customer relationships, Industrial Marketing Management, 39(6), 936-946.

North, D.C. (1991) Insititutions. The Journal of Economic Perspectives, 5, (1), pp. 97-112.

Orlikowski, W.J. (2007). Sociomaterial practices: exploring technology at work, Organization Studies, 28, 1435-1448.

Orlikowski, W.J. \& Yates, J. (1994). Genre Repertoire: Examining the Structuring of Communicative Practices in Organizations, Administrative Science Quarterly, 39, 541-574.

Palmer, M. (2005). Retail Multinational Learning: A Case Study of Tesco. International Journal of Retail and Distribution Management, 33 (1): 23-49.

Perry, C., (1998), "Processes of a case study methodology for postgraduate research in marketing”, European Journal of Marketing, Vol.32, No.9/10, pp.785-802.

Peters et al., 2013

Peters, L.D. Pressey, A. Vanharanta,M. Johnson,W. (2013), Constructivism and critical realism as alternative approaches to the study of business networks: Convergences and divergences in theory and in research practice, Industrial Marketing Management, 42 (3), pp. 336-346

Robinson, P.K. \& Rainbird, H. (2013) International Supply Chains and the Labour Process. Competition and Change, 17(1):91-107.

Robinson, P.K. (2010a) Do voluntary labour initiatives make a difference for the conditions of workers in global supply chains? Journal of Industrial Relations, (52)5:561-573.

Robinson, P.K. (2010b) Responsible Retailing: The practice of CSR in banana plantations in Costa Rica. Journal of Business Ethics. 91(2):279-289.

Robinson, P.K. (2009) Responsible Retailing: Regulating Fair and Ethical Trade. Journal of International Development, 21:1015-1026. 
Sahadev, S. (2005). Exploring the role of expert power in channel management: An empirical study, Industrial Marketing Management, 34 (5), 487-494.

Scott, W.R. (2001) Institutions and organizations, $2^{\text {nd }}$ Edition, Thousand Oaks, CA. Sage.

Skarmeas, D. (2006). The role of functional conflict in international buyer-seller relationships: Implications for industrial exporters, Industrial Marketing Management, 35(5), 567-575.

Truong, Y. Simmons, G. \& Palmer, M. (2012). Reciprocal Value Propositions in Practice: Constraints in Digital Markets, Industrial Marketing Management. 41 197-206.

Tsoukas, H. (2009b). Craving for generality and small-N studies: a Wittgensteinian approach towards the epistemology of the particular in organization and management studies. In Buchanan, D.A. and Bryman, A. (eds), The Sage Handbook of Organizational Research Methods. London: Sage Publications, pp. 285-301.

Tunisini, A. Bocconcelli, R. \& Pagano, A. (2011). Is local sourcing out of fashion in the globalization era? Evidence from Italian mechanical industry, Industrial Marketing Management, 40 (6), 1012-1023.

Turner, J. C. (2005). Explaining the nature of power: A three-process theory. European Journal of Social Psychology, 35, 1-22.

Varadarajan, P.R. (2010) Strategic marketing and marketing strategy: Domain, definition, fundamental issues and foundational premises. Journal of the Academy of Marketing, (38), 119140.

Wood, L. (1999). Market power and its measurement. European Journal of Marketing, 33 (5/6), 612-630.

Yang, Z. \& Wang, C.L.(2011).Guanxi as a governance mechanism in business markets: Its characteristics, relevant theories, and future research directions. Industrial Marketing Management, 40(4),492-495.

Yang, Z. \& Su. C. (2014). Institutional theory in business marketing: A conceptual framework and future directions, Industrial Marketing Management, 43(5),721-725. 
Zhou, N., Zhuang, G. \& Yip, L. (2007). Perceptual difference of dependence and its impact on conflict in marketing channels in China: An empirical study with two-sided data, Industrial Marketing Management, 36(3), 309-321.

Zhuang, G., Alex. X. \& Tsang, S.L. (2010). Power, conflict, and cooperation: The impact of guanxi in Chinese marketing channels, Industrial Marketing Management, 39(1), 137-149. 
Table 1: Institutional Isomorphic Mechanisms in Business Relationships

\begin{tabular}{|c|c|}
\hline Institutional isomorphic mechanisms & Illustrative examples in business to business relationships \\
\hline Coercion (Direct and Indirect) & $\begin{array}{l}\text { The role of society in discrediting an institution or sets of institutions in business exchanges an } \\
\text { industry in business exchanges. } \square \text { Following an economic crisis where institutional transformation } \\
\text { is demanded in business exchanges. } \square \text { The extension of the legal regulations or norms of } \\
\text { rationality, efficiency and legitimacy in business exchanges. }\end{array}$ \\
\hline Attraction & $\begin{array}{l}\text { Market actors actively seek to imitate the attractive institutional solutions to the problems being } \\
\text { faced. } \square \text { In business exchanges, adoption of particular trends, management fashions and agendas } \\
\text { are evident. } \square \text { Voluntary imitation is motivated by the expectation of achieving superior results } \\
\text { after existing institutional models are adopted. Network workshop events, market intelligence, and } \\
\text { scanning tools as well as benchmarking strategy tools, for example, enable the identification of } \\
\text { 'best practices'. } \square \text { The attraction of institutional models is also closely related to socialization } \\
\text { processes in professional training and networks. }\end{array}$ \\
\hline Mimesis & $\begin{array}{l}\text { Mimetic practice is a form of imitation through which actors react to uncertainty with regard to the } \\
\text { effects of institutional rules. } \square \text { In business-to-business exchanges, pressure for accountability } \\
\text { through certification standards and professional industrial associations are evident in industrial } \\
\text { markets. } \square \text { The success of suppliers operating elsewhere (in other regions or markets) provides } \\
\text { legitimation for using them as templates, regardless if any causal relationship exists between the } \\
\text { policy, initiative, strategy and performance can be established. }\end{array}$ \\
\hline Competition & $\begin{array}{l}\text { Competition between suppliers eliminates inefficient institutional solutions. } \square \text { Creates } \\
\text { homogenizing pressures especially if firms have highly standardized products and cannot shield } \\
\text { themselves from cost-based competition through strategies of product } \\
\text { differentiation. } \square \text { Competitive forces may force suppliers to change institutional structures in } \\
\text { parallel ways to become more attractive to buyers. }\end{array}$ \\
\hline
\end{tabular}


Table 2: Instituting a Template of Joint Business Planning

\begin{tabular}{|c|c|}
\hline Dimension of Joint Business Planning & Illustrative Workshop Quotations \\
\hline Jointly agreed forecast targets & $\begin{array}{l}\text { "These are based on sales, profit, volume targets and are supposed to be agreed. However, in my experience } \\
\text { they are not agreed. It is ...[Retail Co's]... way and how they pass on responsibility for us to improve. " } \\
\text { (Interview 17). } \\
\text { "Our joint plan gives us a formalized system to an informal practice. More than that, it gives suppliers the } \\
\text { capacity to grow with us." (Senior Scottish Buying Manager of Retail Co) } \\
\square \text { "It is not joint. It is a template - a blue print - for figuring out how to extract value from our business and to } \\
\text { distribute that value through their business." }\end{array}$ \\
\hline KPIs & $\begin{array}{l}\text { "These are not KPIs as you might understand it. Margins and waste are the key drivers here. How this works } \\
\text { in practice is that Retail Co says - you said you were going to do this? You didn’t and therefore you owe us } \\
\text { money." (Interview 7) } \square \text { "This is not a joint plan. It is simply a list of commercial terms. Purely commercial. } \\
\text { There are no shades of grey with it - simply financial compliance." (Interview 2) } \square \square \text { "It was a case of } \\
\text { wearing us down with charts, tables and statistics - everything was enthusiastic and upbeat [about Retail Co]. } \\
\text { But what about our ideas, our KPIs? What about framing our questions and concerns? There was nothing." } \\
\text { (Interview 5) } \square\end{array}$ \\
\hline Commercial opportunities & $\begin{array}{l}\text { "This is a nice label, but I can tell you that over-riders and volume incentive agreements are not pleasant. } \\
\text { They are a brutal vice grip." (Interview, 14) } \square \text { "There is the own label fear. This is the stick which sits beside } \\
\text { Retail Co at the table of 'negotiation’. They resist anything we say by creating an alternative on their terms." } \\
\text { (Interview 17) }\end{array}$ \\
\hline Product promotional opportunities & $\begin{array}{l}\text { "These are price cut and BOGOF, sampling etc. aspects.” (Local Marketing Manager for the Scotland } \\
\text { region) } \square \text { “These suggest a bilateral decision-making arrangement - in fact the whole thing does. Yet they } \\
\text { keep the surplus, if we over achieve. In effect it is a set of benchmark figures that can’t be altered on the } \\
\text { downside." (Interview 20) }\end{array}$ \\
\hline Product support & $\begin{array}{l}\text { "This is the supplier investment in local initiatives, free stock for events, photography, and advertising. } \\
\text { Listing arrangement and enhanced distribution." (Category Technical Manager for the Scotland region) } \\
\square \text { "They expect us to have field sales support - visits to the sites - but all of these costs are absorbed at our } \\
\text { end." (Interview 15) }\end{array}$ \\
\hline Service Level & $\begin{array}{l}\text { "These are charges for notified shortages and our loss of profit” (Senior Scottish Buying Manager of Retail } \\
\text { Co) } \square \text { "Basically the former part of this commercial agreement extracts value from revenue-enhancing aspects } \\
\text { of the business and the latter part - the so-called support aims to cover Retail Co's cost liability with } \\
\text { suppliers. Either way, we foot the bill." (Interview 3) }\end{array}$ \\
\hline Managing overstocks & $\begin{array}{l}\text { "Significant here is the policy to manage overstocks. Supplier agrees to fund all markdown reselling from } \\
\text { discontinued products" (Senior Scottish Buying Manager of Retail Co) } \square \text { "They are prompting us to visit the } \\
\text { stores, to take a hands-on role. That is a challenge to us and we will have to go away and think about what } \\
\text { this will mean for our resources in terms of field sales support. Getting the right product, the right range, the } \\
\text { right format, used to be the province of the Retail Co. They want more action on this front, but still control } \\
\text { everything from afar" (Interview 14) }\end{array}$ \\
\hline Essential product withdrawal & $\begin{array}{l}\text { "We have to manage supplier negligence at } 1 \% \text { of turnover (Senior Scottish Buying Manager of Retail } \\
\text { Co) } \square \text { “JBP is the footnote at the end of the page that when things go wrong. For the retailer, you said you } \\
\text { were doing this." (Interview 27) }\end{array}$ \\
\hline
\end{tabular}


Figure 1: The Question Flip Chart with Post it Notes

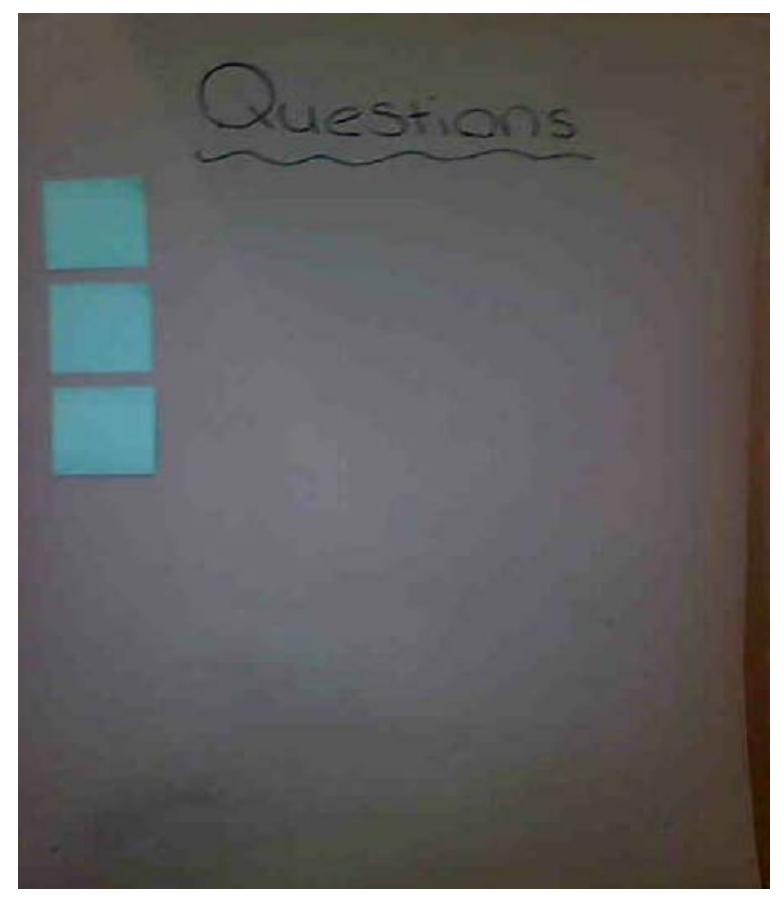


Figure 2: Analysis of Senior Scottish Buying Manager of Retail Co Presentation

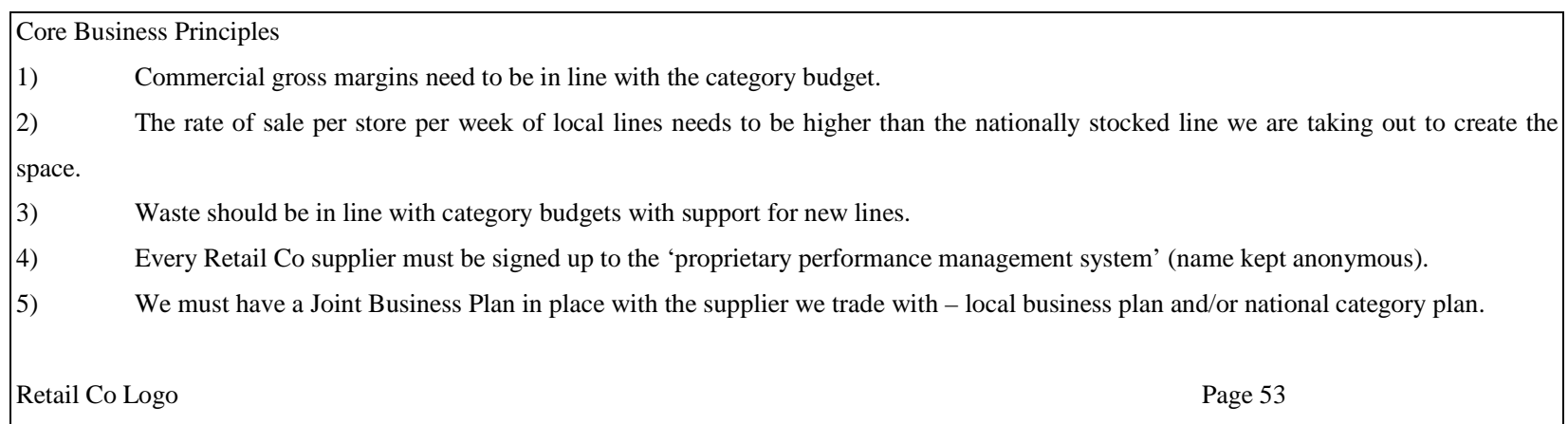

